\title{
Does Community Size Matter in the Settlement Process? The Experience of Syrian Refugees in Lethbridge in Alberta, Canada
}

\author{
Sandeep Agrawal $^{1} \cdot$ Pradeep Sangapala $^{1}$ \\ Published online: 4 July 2020 \\ (C) Springer Nature B.V. 2020
}

\begin{abstract}
The article documents refugee experience in the first year of their settlement in a small city in Canada and then explores whether the size of the community matters in the settlement processes. This is based on an extensive study of Syrian refugee settlement experiences in one large Canadian city (Edmonton) and one small Canadian city (Lethbridge). The findings argue that contrary to existing scholarly literature, small municipalities such as Lethbridge were more creative, nimble, and efficient in settling Syrian newcomers. In small cities, however, lack of denominational and nondenominational organizations to complement government assistance, the onset of compassionate fatigue among the city dwellers, and limited retention of newcomers due to limited employment opportunity are real threats to the settlement process immediately after newcomers' arrival and in the long term. A more substantial role of municipal governments in the refugee resettlement process is recommended to offset the disproportionate burden settlement sector carries.
\end{abstract}

Keywords Syrian refugees · Sponsorship · Community size $\cdot$ Lethbridge $\cdot$ Canada

\section{Introduction}

This article presents some of the findings of a more extensive study that documented the settlement experience of Syrian refugees in the first year of their settlement process in two cities in Alberta-Edmonton and Lethbridge - one large and one small city, respectively. We focus here on the smaller city, Lethbridge, and then elicit differences

Sandeep Agrawal

sagrawal@ualberta.ca

Pradeep Sangapala

Sangapal@ualberta.ca

1 School of Urban and Regional Planning, University of Alberta, Edmonton, Canada 
in the settlement experiences of refugees to this municipality to those in Edmonton. We aim to document refugees' settlement experience in a small city and to elicit differences, if any, related to the size of the community and any other similar factors. The article, however, does not intend to delve deeper into the differences in settlement experiences based on refugee streams.

At present, we find a significant knowledge gap in the literature that builds an understanding of the experience of refugees who settle in small communities, making further knowledge-building essential in this domain. This study, therefore, stands out because of its unique contribution to exploring the linkages between the community size and settlement experience of Syrian refugees. The findings may have significant implications on how federal and provincial resources are distributed for settlement purposes and how refugee targets for each community are determined.

As a brief backdrop, the arrival of Syrian refugees to Canada followed the Syrian conflict that began in early 2011 with mass protests against then-President Bashar alAssad's government, which called for political reforms and the re-establishment of civil rights. The Assad government's crackdown on protestors escalated the violence, plunging the country into a civil war that has displaced more than 5.6 million people from the country (UNHCR n.d.). Arguably, this is one of the largest humanitarian crises in modern history, with many Syrians taking shelter in neighboring Lebanon, Jordan, and Turkey.

Syrian refugee crisis became a single defining issue of Canada's 2015 federal election. Demands for a political response to the humanitarian emergency, partly mobilized by media accounts and photos of young Syrian refugee Alan Kurdi's lifeless body, profoundly changed the course of the federal campaign. The then-Liberal leader Justin Trudeau promised to bring in up to 25,000 refugees by the end of the year 2015 . The idea resonated with Canadian voters resulting in electing Trudeau to power. Since then, Canada has welcomed about 45,000 Syrian refugees (IRCC (Immigration, Refugees and Citizenship Canada) 2018), not only making good on Trudeau's initial promise but also exceeding the initial target.

Canada relied on the UNHCR (also known as the UN Refugee Agency) to carry out the task of identifying Syrian refugees suitable for resettlement. The UNHCR gives displaced individuals a "refugee" status when they pass the agency's screening process and are then "matched" with a resettlement country based on that country's criteria. Canada chose to prioritize those who are most vulnerable, marginalized, and those who are in immediate need of resettlement. These included children, women, families, elderly and disabled persons, members of the LGBTI (lesbian, gay, bisexual, transgender, and intersex) community, and men if they are a part of a family. The Canadian government flew them into Canada and resettled them in various parts of the country based on the local settlement sector's capacity and the number of refugees the sector could support in each community.

The article consists of four sections in addition to this brief introduction. We begin below with a literature review on settlement experiences of newcomers in small communities along with a brief history of Lethbridge as an immigrant and refugee hub. The next section explains the study methodology, which is followed by the findings, comprising multiple subsections with descriptions of settlement experiences within two refugee streams-government and privately-sponsored. The conclusions section wraps up the article by presenting a summary of the differences in settlement 
experience between the two cities, as well as a few policy and programmatic recommendations.

\section{Literature Review}

Our review of the literature on immigration and settlement reveals four broad themes:

1. Limited comparative research exists on municipality size and its correlation with the delivery of settlement services

2. Small communities are particularly overlooked in the scholarly research on refugee settlement experiences

3. Attracting and retaining newcomers is a key issue in small communities

4. Settlement workers in small communities have an especially challenging task to deliver services because of the lack of available resources and refugees' prolonged involvement in the settlement process

Few studies have investigated the settlement experience of immigrants and refugees in small communities across Canada. It is well-known that Canadian immigration and settlement studies have a bias towards the three large cities of the country: Toronto, Vancouver, and Montreal (c.f. Danso 2002; Garcea 2016; George and Tsang 2000; Hansson et al. 2012; Hiebert 2000, 2017; Hou and Beiser 2006; Simich et al. 2005; Teixeira and Li 2009; Wood et al. 2011). This is expected, as most immigrants and refugees settle in these three metropolitan areas. There is, however, increasing scholarly attention to medium-sized cities such as Edmonton, Calgary, Winnipeg, and others, as these areas have attracted more immigrants in the last decade or so (Abu-Laban et al. 1999; Agrawal 2018; Derwing and Krahn 2008; Enns and Carter 2009; Frideres 2006; Hyndman et al. 2006; Krahn et al. 2005; Lo and Teixeira 2015a; Radford 2007; Teixeira 2009; Walton-Roberts 2006). Further, a serious dearth of studies exists on settlement experience in small communities with a population of around 100,000. Some studies do shed light on the emerging interest of immigrants to establish in small communities (Citizenship and Immigration Canada 2001; Frideres 2006; Radford 2007), but it is a relatively recent phenomenon (Bonifacio and Drolet 2017). Thus, an investigation such as this one is both necessary and timely.

The prevailing literature on small communities mainly focuses on the issue of retention of newcomers. Contrary to large cities, most small communities failed to attract or retain newcomers (Abu-Laban et al. 1999; Derwing and Krahn 2008; Drolet et al. 2008; Hyndman et al. 2006; Krahn et al. 2005; Sethi 2013; Sherrell et al. 2004; Teixeira and Drolet 2018). Scholars argue that the absence of adequate settlement services, employment opportunities, and facilities for higher education are key barriers to retention. Also, most newcomers encounter challenges in finding affordable housing (Teixeira and Drolet 2018) and essential services such as health care in small communities (Drolet et al. 2008). Most immigrant entrepreneurs in small communities also encounter obstacles in establishing businesses due to the small threshold and market range (Lo and Teixeira 2015b). Despite receptivity towards newcomers, many small communities have been unable to provide adequate economic opportunities and settlement services to enhance the experience of newcomers (Citizenship and Immigration 
Canada 2001; Derwing and Krahn 2008; Hyndman et al. 2006; Krahn et al. 2005; Sherrell et al. 2004).

Concerns that go beyond the economic are also factors for refugees in smaller municipalities: The attitudes local residents hold towards newcomers and how welcoming they are (or not), as well as the refugees' desires to live close to their family members and compatriots also affect successful retention and adaptation (Bonifacio and Drolet 2017; Citizenship and Immigration Canada 2001; El-Bialy and Mulay 2015; Krahn et al. 2005; Sherrell et al. 2004; Williams et al. 2015). Overt racism and discrimination are also mentioned as possible reasons as challenges for settling in smaller and rural places (Clement et al. 2013; Esses et al. 2010; Esses et al. 2013; Hallström 2018). Unlike the large cities, which encompass broad ethnic and cultural diversity, most newcomers find difficulties in meeting the social conditions in small communities (Derwing and Krahn 2008; Derwing and Mulder 2003; Hyndman et al. 2006; Walton-Roberts 2005). The refugees and migrants who came from more cosmopolitan urban geographies become distressed when they arrive in small and relatively less diverse towns (Citizenship and Immigration Canada 2001; El-Bialy and Mulay 2015).

The recent literature argues that the settlement agencies play a vital role in enhancing the settlement process of the newcomers in small communities (Ashton et al. 2016; Drolet and Robertson 2011). Settlement workers in small communities play multiple roles in multiple stages of the settlement process - from the initial arrival to the long-term stay of newcomers (Drolet and Robertson 2011). They also confront many more challenges in assisting newcomers (Ashton et al. 2016; Drolet and Robertson 2011; Sherrell et al. 2004; WaltonRoberts 2006). Because of the lack of adequate capacity, they typically feel overwhelmed in providing services to newcomers (Ashton et al. 2016).

Hyndman et al.'s (2006) study makes the most explicit link between the city size and attraction and retention of newcomers. The study points to the tautological logic that immigrants are attracted to cities where they can find an existing immigrant population and their friends and family. While some studies have focused on newcomers' settlement experiences in small urban centers (Bonifacio and Drolet 2017; El-Bialy and Mulay 2015; Krahn et al. 2005; Walton-Roberts 2005, 2006), possible linkages between the size of the community and the delivery of settlement services are not fully explored.

Abu-Laban et al.'s research (Abu-Laban et al. 1999) is the most relevant and arguably the only study that systematically examined the settlement experiences of refugees based on the size of the host communities in Alberta. They found that the refugee retention rate was highest in the larger cities of Edmonton and Calgary and lowest in the smallest cities of Grande Prairie and Fort McMurray. Among the mediumsized cities, Lethbridge had the lowest retention when compared with Red Deer and Medicine Hat. Refugees tended to move to the nearest larger cities in the province. For instance, $25 \%$ of refugees destined to settle in Lethbridge eventually moved to Calgary while $33 \%$ of refugees destined to settle in Grande Prairie and Ft. McMurray subsequently moved to Edmonton. Among the primary reasons for leaving was the lack of both employment and education. A more recent study by Fang et al. (2018) also points to the potential scarcity of employment opportunities in small- and mediumsized cities, specifically in a Newfoundland and Labrador context, noting that this undermines Syrian refugees' retention in these communities. 


\section{Lethbridge}

The city of Lethbridge is the regional hub for economic, commercial, and public services in southern Alberta. As Bonifacio (2017) puts it, the city stands at the "crossroads of four major highways," (p. 80) connecting to the city of Calgary in the north, the U.S. border in the south, the nearby Trans-Canada Highway, and the regions of British Columbia to the west and Saskatchewan in east. Along with large stretches of prairie fields, the Lethbridge area includes many lakes, irrigation systems, and various landscapes and topographies.

During the late 19 th and early 20th centuries, coal mining played a significant role in Lethbridge's economy, like most cities in the regions (Ellis 2001; Johnston and den Otter 1985). The mining industry collapsed however with the development of other energy sources such as oil and natural gases (Ellis 2001). Despite oil and gas, agriculture is still a significant economic engine of the Lethbridge area. Currently, along with its diversified agricultural practices, Lethbridge has become a regional pioneer of bio-industrial and agri-business (Economic Development Lethbridge 2017). Still, the public sector remains active in the city's economy. According to the Economic Development Lethbridge (2016), half of the workforce in Lethbridge are public sector employees, mainly in health care, education, and government services.

In 2016 , Lethbridge had a population of close to 100,000 (96,828 to be exact), which makes it the fourth largest and the fourth most populated city in the province of Alberta - after the cities of Calgary, Edmonton, and Red Deer. Lethbridge is home to a substantial population of Indigenous residents and immigrant communities from across the country and around the world. Local educational institutions, such as the University of Lethbridge and Lethbridge College, also contribute to the city's population diversity by attracting over 15,000 domestic and international students each year (Bonifacio 2017).

\section{Immigrants and Refugees in Lethbridge}

Like most cities in Canada's prairie provinces, immigrants significantly shape Lethbridge's demographic profile, economic growth, and social landscape. The history of immigrants in Lethbridge goes as far back as the late nineteenth century when the city was initially formed. By the early twentieth century, the coal mining boom attracted many immigrants from America and Europe, (Ellis 2001), including diverse ethnic groups-English, Scots, Irish, Welsh, French, Russian, Austrian, German, Swedish, and Italian (Ruttan 2018). According to Kovacs (1981), Lethbridge also became a "major Hungarian center in early Alberta" (p. 52), with many Hungarians employed in the mines. Notably, Canadians also moved from the east, and British and American immigrants emerged as new elites of Lethbridge in the early twentieth century (Bonifacio 2017). Many immigrants from Asia, mostly Chinese and Japanese, also arrived in Lethbridge in the first half of the twentieth century (Bonifacio 2017; Li 2008; Yamagishi 2010). Most of them were involved in railway construction and farming activities. Unfortunately, the "non-white immigrants" experienced considerable discrimination and social exclusions during the early stages of their settlement process (Bonifacio 2017). 
As of 2016, Lethbridge has about 15,365 immigrants or about $15.8 \%$ of the total population. This figure reveals an increase of 3405 in the immigrant population from 2011. According to the 2016 Canadian census, most foreign-born individuals in Lethbridge were Europeans (around 5840), with most arriving from the UK (1825) and the Netherlands (1505). Asians were the second-largest immigrant population (4510), with Filipinos (1230), Chinese (520), and Indians (410) making up the largest share. Americans and Mexicans remain the two other predominant immigrant groups in Lethbridge.

Lethbridge has been a destination for refugees over the last few decades as well during the last century. In addition to Syrian refugees recently, Lethbridge has had refugees from Kosovo, Sudan, Bosnia, Afghanistan, and Bhutan. Unlike other small communities, most refugees who arrived in Lethbridge remain in the city. For example, the Kosovo refugees who arrived in Lethbridge in the 1990s had a relatively higher retention rate than the refugees who moved into other small communities like Fort McMurray and Grande Prairie (Abu-Laban et al. 1999). Currently, 20\% of the total Bhutanese refugees (over 1000 individuals) who arrived in Canada since 2007 live in Lethbridge (Bingley 2016; Klingbeil 2016; Tams 2014). They have successfully established themselves in Lethbridge by building strong social networks, making it "Canada's capital of Bhutan" (Klingbeil 2016).

\section{Method}

The study entailed semi-structured, face-to-face individual interviews with refugees and key informants to gather accounts of settlement experiences. Syrian refugees, the staff at Lethbridge Family Services (LFS) and Alberta Health Services (AHS), and private sponsors in Lethbridge were selected as interviewees. As of May 2016, Lethbridge received 174 government-assisted refugees (GARs), ${ }^{1} 19$ privately-sponsored refugees (PSRs), ${ }^{2}$ and 0 blended Visa Office-referral program refugees (BVORs). ${ }^{3}$ As of January 2017, these figures were 243, 24, and less than five, respectively. ${ }^{4}$ Between October 2016 and June 2017, the research team interviewed 17 individuals in Lethbridge who were either GARs or PSRs.

Immigration, Refugees, and Citizenship Canada (IRCC) chose LFS as the provider of the Resettlement Assistance Program, which provides settlement services to GARs settling in Lethbridge. The Government of Canada uses such programs to directly fund the provision of immediate and essential services to government-assisted refugees; it is also a means to fund some services to

\footnotetext{
${ }^{1}$ The government-assisted refugee program (GAR) is for those refugees who are referred to Canada by the UNHCR based on the Government of Canada's criteria and are then sponsored by the Government to resettle in the country. The support to the refugees is delivered by non-governmental settlement agencies, which are funded by Immigration, Refugees, and Citizenship Canada (IRCC).

2 The privately sponsored refugee program (PSR) is a program in which a private sponsor agrees to provide refugees with care, lodging, settlement assistance, and support. Nuanced variations exist, such as groups of individuals or church communities who collectively sponsor a refugee family.

${ }^{3}$ The blended visa office referral program (BVOR) is a relatively new program (as of 2013) that matches refugees identified for resettlement by the United Nations High Commissioner for Refugees (UNHCR) with private sponsors in Canada.

${ }^{4}$ As of January 2017, Edmonton received 1248 GARs, 607 PSRs, and 138 BVORs.
} 
privately-sponsored refugees. Because of their engagement with so many of the refugees, we relied on LFS to identify interviewees for us. We interviewed three key settlement agency staff members who deliver services to the Syrian refugees. We reached out to two private sponsor organizations - the Lethbridge Mennonite Church and the Anglican Church of the Ascension-and interviewed one representative from each sponsor. One key informant from AHS, who worked closely with LFS, was also interviewed.

The team developed two sets of questions - one for sponsored families and another for settlement agency staff and private sponsors. Questions for refugees were slightly more structured than those for the sponsoring and settlement agencies and were divided into six sections that covered basic demographics, the settlement trajectory, reflections on their settlement experience, health conditions, social and economic integration, and their future plans in Canada.

The interviews with the refugees were held face-to-face in Arabic, while interviews with the settlement workers and sponsoring families were primarily in English. Two research assistants, who are Syrian refugees themselves, led the interviews with refugees. Interviews were held at LFS's premises for about 45 to $60 \mathrm{~min}$ and were digitally taped and transcribed by the two research assistants with assistance from the collaborator. A research collaborator who is fluent in Arabic and is a seasoned researcher also participated in the interviewing refugees and later on ensured that the transcriptions were accurate. The transcribed interviews were then analyzed using Nvivo software for recurring patterns, common themes, and types of support that elicited concerns among refugees, private sponsors, and the settlement agency.

Questions for the settlement agency staff or sponsoring families were openended to elicit the agencies' or families' views on the challenges and opportunities that Syrian refugees faced after their arrival in Canada. Both agency personnel and sponsors were also given the opportunity to share the challenges they faced in serving and settling the refugees. The questions for the sponsors, in particular, aimed to elicit their experiences in sponsoring a family and to uncover any challenges they might have faced during the sponsoring and settlement process.

\section{Findings}

\section{Refugee Sample Profile}

Ten households were interviewed in Lethbridge, constituting a total of 17 individuals, of which 10 were women. The mean number of people to make up a household was 4.3 individuals, with an average of 2.1 children per family. Out of the 17 individuals interviewed, two were single, two were widows, and the remainder were married. The average age of the interviewees was 31 years. Fifteen came as GARs while two arrived through the PSR stream. Most of the interviews were held with all the Syrian family members; it is essential to note that when male family members were present, they dominated the conversation in almost every interview we had with GARs. 


\section{Feedback from Government-Assisted Refugees}

Refugees' General Impressions When we asked interviewees about their expectations before arriving in Canada, most of them said that they had heard that Canada is a nice country. However, it turned out to be more than simply nice. They were overwhelmed by Canadians' generosity when they first arrived in the country. Many were content with the freedom of belief and opinion. Everyone expressed their respect and gratitude to the Canadian government for all the effort it had put into bringing them here. Indeed, they wished the government could also resettle their relatives or other people from Syria.

The major obstacle in establishing and maintaining relationships with Canadians was the language barrier, just as was the case with refugees in Edmonton. Some had problems in communicating with their children's teachers, doctors, or even people at grocery stores. However, some have been innovative and are using mobile phone translation applications to communicate with English-speaking Canadians.

When we asked women about challenges they may have faced when settling in, some felt welcomed and, specifically, not judged for the way they dress. Others, as noted above, were unable to understand the language. Single, widowed mothers with dependent children were mostly concerned about what would happen to them when the government assistance expired in a year. This was especially a worry since they had no male support, were not used to working outside the home, or did not have a prior profession in their country of origin.

Regarding month 13 (when the government assistance would run out), some families were optimistic, saying that if they found jobs they would have nothing to worry about. Others, however, were concerned that they would not be able to learn English and thus would not be able to work full time to provide for their families. The following quotes from two different interviews capture the above concerns and views:

We are optimistic about it. If we find jobs, we will not worry about anything.

I only have three months left to finish my first year, but I am still in level 2. This means that one year is not enough to have a good command of English.

When the men were asked about their future plans, they said they would like to find any job they could get. However, for the most part, the men said they wished to first graduate from the English program before starting to work. Others were trying to find part-time jobs while studying English, and some had plans to start their own businesses. Some of these sentiments are reflected in the following quotes:

I will work in any job. I heard that there are not many jobs in the field of laying ceramic tiles and [also] because the winter is long and you cannot work outside in the cold. I am used to working in paving the streets and house flooring. So, I will work in any job until I can find a job in a ceramic installation, which is easier for me. 
I would like to continue studying English at school. Right now, I am between levels 2 and 3; just one more step and I will be in level 3. I want to do at least level 4. Also if I have the chance I want to study in college. Like you said, after a couple more months, the sponsorship will end. If I have to work I will, but if I can continue studying at the college, I will [do that].

Arrival Experience When asked about their views on services received upon arrival in Canada, families in Lethbridge had similar experiences to those of Edmonton families. Settlement workers would pick them up from the airport and drive them to a hotel. They would give them money to buy food and whatever they needed. Then, the settlement agencies would start assisting them with other needs, including housing, health, education, and life in Canada more generally.

Families explained that settlement workers helped them with the majority of the paperwork and providing them with translators whenever needed. They also helped with practical tasks, such as registering them at the English school or their children at the elementary school, showing them the bus routes and how to ride the bus, and so on.

One of the refugee women had to travel to Canada while she was sick, so a doctor accompanied her all the way from an airport in Jordan to Lethbridge to make sure she arrived safely in Canada. The following quotes from different interviewees capture the heartfelt gratitude refugees feel towards Canadians and the Canadian government:

We arrived at night and they gave us a ride to the hotel. Fortunately, my brother arrived here 11 days before us and we met in the hotel. So, they put us in a hotel for 15 days, me and my wife and daughter, and they gave us some money.... I really do not remember the amount but it was enough for the first period, for food and beverages. Then we found a house and rented it.

We are good, and nothing is missing. They do whatever we ask-they are treating us well.

In the airplane, I started to cry, but when I saw how they are treating us and that everyone is smiling and welcoming us-thank God, I felt happy.

Because my mother was sick, a doctor came to the airport from Jordan, and he came with us to Lethbridge....Moreover, there was a nurse on the airplane; she took care of my mother. Later when we arrived, an immigration employee and [an] interpreter welcomed us in the airport. No other government did what the Canadian government is doing for us.

All the families agreed that their children's education was a top priority for them and that education could help them secure a better future for their kids, better than the one they had. While the kids attended the school or were at daycare, their parents attended the English classes.

Sponsorship Program When asked about the differences between their own sponsorship and other programs such as PSRs and BVORs, most of the GAR families were not able to identify their own sponsorship type. Families knew more about the services they 
were getting and only a little about the services that their Syrian friends were receiving. They also could not specify which sponsorship program their friends had arrived through.

Some Syrians thought that services provided to both PSRs and GARs were excellent, with a few noticeable differences. Some GARs thought that the PSRs were getting the same services, but faster. They attributed this difference to sponsoring families, who were personally following up on the PSRs' needs, instead of an agency that has to cater to more people. They also thought that PSRs were establishing more connections and relationships with the non-Syrian community because of the existing network of the sponsoring families:

We do not know the services provided to them (PSRs), but when they want any service, I feel like they can get it faster. If they want some medical service, it is arranged faster by a person than by an office. Moreover, you feel that they have more friends and relations so that is why their services always go faster, especially in medical services or others. However, in general, both are good.

On the other hand, the GARs had access to interpreters, which PSRs did not necessarily have, especially when none of the sponsoring family members spoke Arabic.

Missing Services When asked if they felt any services were missing, most of the families stated that 1 year of government support is not enough for them. Others suggested that the amount provided by the government barely covers their rent, insurance, bus passes, phone, and so forth.

Others suggested that there should be a more extensive English training program to help them better communicate in English. These classes also need to run at more convenient times for parents. Others spoke about the need for improved quality of teaching techniques and teaching material at the language school:

Honestly, I expected financial assistance for small families like mine to be more because the rent is expensive....For example, $\$ 810$ for the rent, $\$ 65-\$ 60$ for electricity, insurance, etc.... Where is the $\$ 1550$ [the allowance]?! Gone. Do we live on water only?!

If you want to work, you can find an eight-hour job, but my school is in the morning. It's impossible for me to find a part-time job. No one will hire me parttime.

Health When asked about their general health, the refugee families thought they were mostly in good condition. About half of them, however, underwent various forms of surgery or were on medication for chronic illnesses such as epilepsy, iron deficiency, allergies, and blood pressure issues.

A few had dental health issues, which required extensive work. Most of the extensive dental work was not covered under the federal healthcare plan and a couple of refugee families ended up bearing the entire cost and were obviously not happy about it. 
When asked about health services in Canada, the families stated that the quality of health services is better than back home in Syria and that the doctor will do all needed tests, even if the person only has the flu:

Health services [in Canada] are outstanding. I know many Syrians underwent surgeries here in Canada without paying anything. Thank God! I did not need any surgery in Canada, because I did [that] in Lebanon. The UN paid $\$ 6000$ and I paid $\$ 3000$ for the surgery.

Nobody can say anything bad about the health services [here]. Canada is well known internationally for that, and it is obvious, without the testimony of the Syrians.

Clearly, health care services to Syrian refugees in Lethbridge were relatively more efficient and effective. This can be attributed to the new model of health services to Syrian refugees employed in Lethbridge, which is explained later in the article. Contrarily, in Edmonton, refugees complained about the long waittimes to see their family doctors and specialists for any non-emergency care (Agrawal 2018).

Economic Integration The GARs in Lethbridge came from a variety of different occupations. Many in our sample were women with no or minimal work experience outside the home prior to coming to Canada. Some men in our sample were business owners of a supermarket and a food distribution company. Occupations among the others included work as a driver, an electrician, in an outdoor clothing store, in a footwear factory, and selling restaurant equipment. In Canada, at the time of the interview, all of them were unemployed except one, who worked on a poultry farm. Almost all of them were eager to work and wished to work in the areas in which they had some experience and skills from their home country. However, they also thought this was wishful thinking. Most likely, they would have to learn English first or get further education or vocational training in Canada.

Social Integration Language challenges were a significant barrier in integrating with the rest of society. Despite the interpreters provided by the settlement agencies, our interviewees had difficulties in communicating. The interpreters were available only during working hours, and thus, many of the Syrians sought assistance from their English-speaking friends or relatives.

As expected, the recently arrived Syrians were mostly dependent on the settlement workers, volunteers, or friends to help them navigate the system and access services. However, Syrian families who have been in Canada longer seem to become gradually more independent. Eventually, they no longer need assistance from the settlement workers.

Interestingly, the children of the Syrian families help their parents communicate with others and learn the language. The following quotes tell us that refugee children are learning English faster than their parents and helping their parents by being their interpreters: 
His English is better than mine. Sometimes he says, "Mom, they are saying that" [that is, a specific word or meaning].

When we go to the supermarket he can understand what they are saying better than me. He is our interpreter, the family interpreter.

When we asked about their relationships with other families or associations, we noticed they still have limited connections with the community, apart from the sponsoring families or volunteers. Some of them have established relationships with other Syrian families at the school or have met families from several backgrounds at the mosques, churches, or parks:

There is a small worship place, which is very small usually. Of course, in the city, we go there on Fridays. I feel better when I see others.

There is this volunteer, but our relationship is superficial. We went to her house once only, as it was her daughter's birthday. Also, she used to visit us, but she wasn't useful at all. She used to stare at her cellphone. She did not do anything for us.

Long-Terms Plans When asked about future plans in Lethbridge, most wished to stay in Lethbridge but were anxious to find jobs. They were eager to first graduate from the English school before starting to work. Others were trying to find part-time jobs while learning English at the school, while some others had plans to start their own businesses. Men generally said that they would like to find any job until they could find something related to their profession. Women, on the other hand, had not thought much about the future. Some women expressed interest in looking into learning new skills or professions such as hairdressing, sewing, and so on, but none had seriously considered a career start or career shift. The following quote reflects what many refugees were thinking of studying and working at the same time:

I told you I cannot study and work. I tried to work for two weeks then I quit because I used to finish school at 3:30 then I go to work from 4 till 11:30. Then, I go home ... oh my God.

\section{Privately-Sponsored Refugees (PSRs)}

Sample Profile and Feedback from Refugees We interviewed only two Syrian refugee families in Lethbridge who were privately sponsored by a local church. The female in one family was a teacher in Syria, and the male in the other had multiple jobs, including farming and running a restaurant business. We found that these families had established excellent relationships with the sponsoring families. Both families could not identify the differences between the services their sponsoring families provided to them from the ones the government provided to other families. They were fully satisfied with the services they received from their sponsors. 
Even though family members were enrolled in English classes and attended them regularly, language remained the major obstacle for these families - just as with the Edmonton families. Still, despite the language barrier, members of one family had obtained employment in construction. We also interviewed an older, retired individual, whose daughter (who had been in the country for some time and worked as a teacher) had sponsored him with the help of a local church. Both this man's two sons had also found employment. One of these PSR families commented that the church was helping them sponsor their daughter and her family, making it possible for them to also come to Canada. Obviously, this type of assistance was not available to GARs.

\section{Feedback from Settlement Agencies and Private Sponsors}

When we asked the sponsors and settlement agencies about their thoughts on the educational background or skills of the Syrian refugees, they reported that most of the Syrians did not have a university degree and lacked specialized skills. As well, they thought those coming to Lethbridge were mostly from rural areas in Syria and did not speak English.

When asked about the efficacy of the English classes in Lethbridge, the settlement workers reported that they did not have Language Instruction for Newcomers to Canada (LINC) class, but the available English classes were somewhat flexible in that they accepted mothers who attended with children under the age of six. The classes also used different teaching styles to accommodate people with different learning abilities, such as both visual or tactile. They did report that Lethbridge needed more ESL teachers to meet the needs of all the newcomers, along with sustained funding for English classes, and especially those for people with learning disabilities. Further, the programs must be designed to encourage and support more women to learn English, enabled in part by providing their children with other activities.

The settlement workers identified several needs when asked about refugees' health in general. They noted that some refugees arrived in Canada with significant chronic health issues, and most of the children and their parents had severe dental problems that were not covered under the Interim Federal Health Program basic dental plan. Thus, they argued for the need for proper dental coverage for the refugees and also called for more female doctors in Lethbridge and special programming for kids and parents who may have mental or physical disabilities. As well, they recommended expanding funding for the primary care network - to conduct awareness and informative sessions on safety, domestic violence, child abuse, parenting, driving, rules and regulations, and public health in general.

One of the significant accomplishments of Lethbridge in settling Syrian refugees is the collaboration between AHS (Chief Medical Officer of the South Zone) and the LFS. This collaboration led to the creation of a multidisciplinary healthcare clinic, which facilitated refugee access to a family physician and other immediate medical needs within the first $48 \mathrm{~h}$ of their arrival in Lethbridge. Within 2 weeks of arrival, most refugees were able to attend a primary healthcare clinic. The clinic was one-stop-shop that had public health nurses who could do immunization and oral health screen and was also equipped with a lab to conduct all forms of testing and screening. 
When the settlement agencies and sponsoring families were asked about how Syrian families were adapting to life in Canada, they reported various issues and challenges. For instance, some Syrian Muslim families could not tolerate eating non-halal products or even working in the poultry/meat industry - an employment sector in Lethbridge which offered some of the few available jobs. However, these informants also noted that most refugees who came from rural areas were happy to settle in a small town like Lethbridge, instead of other big Canadian cities.

The settlement workers also commented that refugees were grieving over the family members they had left back home. Even though the first 6 months after their arrival were focused on how everything was exotic and fabulous in their new home, as the refugees acclimated to their new surroundings, they could suddenly experience sorrow and feelings of significant loss. This was the experience of almost all the refugees.

In response to our question about whether refugees are prepared for month 13, the agency predicted that refugees with larger families would experience some financial challenges - although these families might still get some help from the child tax benefits. Overall, both settlement agencies and private sponsors were trying to help families get established for their long-term stay, but most of the families remained inadequately prepared for month 13 . The families needed more time to learn English and really be prepared.

The workers took pride in reporting how supportive and welcoming the Lethbridge community was to the Syrian refugee families. Some Canadian kids would play a game called "spot the Syrians" and would stop by and say "hello." Some business communities expressed their interest in mentoring Syrian refugees who were planning to open their own businesses in Lethbridge. As well, the University of Lethbridge organized classes on weekends to guide refugees as to how to kick-start their own business in Canada.

The settlement agencies suggested the following few ways to improve the settlement process:

- Because some children arrived with a developmental disability (physical or mental), there is a need for closer, adequate follow-up with these children and their families.

- More efficient collaboration is needed between the settlement agencies and other stakeholders engaged in the settlement process. Such collaboration will help to support refugee families to receive information about their extended families who are left behind in asylum countries, as well as aiding in the follow-up of the children with developmental disabilities noted above.

- Some Syrian families reported incidents of domestic violence perpetrated by the male figure in the family against the spouse or children. The settlement workers reported that most of the women who are victims of domestic violence are still reluctant to report the abuse, although a small number of women came forward and wanted the police involved. An awareness program is needed to introduce refugees - both men and women - to Canadian laws and regulations and help them learn how to abide by them or to seek help from the law enforcement agencies.

- Increasing funding to promote community awareness about inclusivity and diversity should become a priority. This could help avoid any possible inter- and intracommunity conflict among the refugee populations on one side, and the refugees and the Canadian-born community on the other. 
- The government should consider more programming to extend the financial support for Syrian refugee families beyond the first year of their arrival.

\section{Conclusion}

We began this study with an interest in exploring the settlement experiences of Syrian refugees in Alberta. We focused on assessing differences and factors mediated by the size of the community in which they settle in Canada. Specifically, we considered how recent Syrian refugees navigated the settlement and integration process and what services, if any, may be missing that would have facilitated their settlement in Canada. Because of the overall small sample size of the interviewees with few or none in two of the three refugee streams, we did not aim to look for differences among the refugee streams.

The refugees' main points of contact were varied, for instance, settlement workers for GARs and private sponsors for PSRs. Friends and families also helped them in their settlement process. Children of refugees learned English faster and began to help their parents and others who were in a similar situation. In terms of missing or inadequate services, our interviewees pointed to insufficient availability and quality of English classes, lack of vocational training programs, and certain types of dental work not covered by the Canadian health system. They also complained that 1 year is too short a period for a family to become financially independent.

We found both commonalities and differences in the settlement experience across the two city sizes. In both cities, the refugees' challenges were partly rooted in their own intrinsic qualities - that is, the human capital assets (or lack thereof) they brought with them. Examples here included (a) the lack of ability to speak English or to learn it quickly — which may be affected by their educational level, and (b) their professional or employment backgrounds. Together, these factors created some severe challenges in finding employment in Canada. Refugees in both cities were not adequately prepared for month 13 - the point at which they were expected to become financially independent because the government or private support ended then.

Contrary to the consensus in the existing literature about refugees' preferences regarding the size of the municipality in which they settle, our interviewees stated that they wanted to stay in Lethbridge and make a home there. However, they were all concerned about finding appropriate local employment. We did not learn whether, in fact, our refugee informants did stay in Lethbridge after the end of their first year there.

Edmonton and Lethbridge present two different economic contexts. In Edmonton, employment is mostly in the service sector and the oil and gas sector; in the Lethbridge area, more jobs exist in farming, cattle feedlots, chicken farms, and pork and poultry operations. In fact, chronic labor shortages exist in both Canadian agriculture and meat processing industries, mostly in Alberta (Stephenson 2019). The refugees were, however, disadvantaged in both locales primarily because of their deficiency in English language skills, even when they might have some relevant occupational skills. Jobs in the agricultural sector in Canada (mostly available in Lethbridge) have become mechanical and technical in nature over the years so that refugees seeking employment require sufficient knowledge of English and perhaps certifications in particular machinist skills. Obviously, lack of English proficiency and Canadian certifications made 
access to these jobs difficult. Finally, some refugees had issues working on pork farms because of religious reasons (whether due to the handling of animal products or because pork is not acceptable in a strict Muslim diet).

Canadians in both urban centers were generous and provided a significant volume of donations to help out refugees. In return, refugees were equally grateful for the help they received. In our sample, one refugee family who resettled in Lethbridge asked specifically to be moved to Edmonton as they did not have any family or friends in Lethbridge, while one of their relatives was resettled in Edmonton. They wished to be close to this relative.

We noted the following additional differences between the two cities:

1. Contrary to the existing literature (Bonifacio and Drolet 2017; Citizenship and Immigration Canada 2001; El-Bialy and Mulay 2015; Krahn et al. 2005; Sherrell et al. 2004; Williams et al. 2015), settlement services in Lethbridge seemed adequate for the number of refugees who have settled there. Edmonton, on the other hand, faced a severe shortage of spaces in LINC classes, affordable housing, interpreters, and other services (Agrawal 2018). It seems that smaller municipalities, such as Lethbridge, where the refugee numbers are also small were better prepared within the existing or slightly expanded settlement infrastructure. Because it is smaller, compared to a city like Edmonton, Lethbridge had better connections among the organizations and individuals involved or interested in the settlement sector. Hence, this city could access people and resources on short notice.

Also, we wonder if perhaps there is a threshold number of newcomers that an urban center can handle. We surmise that limits exist, tied to the scale and efficiency of settlement agencies, a sudden surge occurs of newcomers who are largely dependent on the government and settlement services. Our data suggest this is likely true regardless of the size of the municipality. Moreover, of course, the number and types of jobs available are limited; this is an aspect of resettlement that is mostly independent of the settlement services themselves.

2. In large centers, such as Edmonton, many service gaps - as well as culturally and linguistically appropriate services - were fulfilled by local denominational and non-denominational organizations, like local mosques, Islamic Family and Social Service Association (IFSSA), and Action for Healthy Communities (Agrawal 2018). These organizations improvised services and sometimes customized them to suit the immediate needs of the refugees. This included, for instance, providing them with halal food, furnishings for their homes, interpreter services, and much needed vocational training. These services were missing in the smaller municipality of Lethbridge.

3. A small place such as Lethbridge could reach its "compassion fatigue" much faster as one settlement worker alluded to in the following quote:

Now that honeymoon phase is over and there is no more big-time donation and they [refugees] have to spend their own money for diapers, for baby formula, and for food. We are finding that obstacles and resistance. So I think they [refugees] are getting an understanding that now you need to be responsible for your owns things. 
The fatigue was happening partly because relatively fewer people are involved for an extended period of time in the refugees' resettlement process. The other possible issue in a small place is those earlier cohorts of refugees may feel that they might not have received the same level of treatment and reception Syrians received. This could lead to a fractious and contentious relationship among different newcomers' groups, with the potential to accelerate over time.

4. Lethbridge was exceptional in its medical service model, which created a one-stop medical clinic where all Syrian refugees could go for initial medical check-ups, immunizations, and referrals to specialists. As noted, this came about through the unique collaboration between the LFS and the Chief Medical Officer of the South Zone of AHS, which resulted in a multidisciplinary healthcare clinic providing necessary care to all Syrian refugees coming to Lethbridge within the first 2 days of their arrival. This model, which was a brainchild of the Chief Medical Officer, has the potential to be employed in other jurisdictions.

5. The general impressions from the Lethbridge-destined Syrian refugees and settlement agencies mostly contradict Abu-Laban et al.'s (1999) findings, which had documented a lukewarm reception to refugees in Lethbridge. In fact, when compared against Edmonton, Syrian refugees in Lethbridge reported higher satisfaction with the settlement services offered to them, as well as with the community they lived in. Issues such as language and job training, and assistance, however, remain a perennial problem in both Edmonton and Lethbridge as was documented in AbuLaban et al.'s study from about two decades ago.

6. Our interviews with the refugees and settlement workers confirmed that the residents of Lethbridge welcomed the newcomers with open hands. They showered them with clothing, furnishing and other daily essentials of living in addition to volunteering their times in helping them with the minutiae of daily life, for instance helping them bring their groceries or how to ride the busses. This welcoming attitude is in contrast with the prevailing belief and the existing literature. This could be partly because Lethbridge has had a history of welcoming immigrants and refugees since its inception. However, according to Rural Development Insitute (2016), receptivity of refugees is usually positive during recent refugee resettlement but typically after 6 months, interest may start to wane.

The ratio of newcomer numbers to the capacity of service infrastructure present (regardless of the size of the urban center) matters because it largely determines the efficacy of the settlement services. IRCC does its own set of analyses based on community capacity and consults broadly, including within the settlement sector. It is, however, not clear to us whether and how detailed analysis of the settlement sector's capacity was conducted in determining the Syrian refugee target for each urban center of Canada. Nonetheless, larger urban centers such as Edmonton have other advantages. For instance, they have "other" non-denominational and denominational organizations that stepped in to fill the service gaps and provided more culturally and linguistically appropriate services. It is unclear whether this informal settlement sector was considered as a part of determining the community capacity.

An interesting aspect of the refugee resettlement process is a passive role municipal or provincial governments play despite the fact that a vast majority of refugees are settled in urban centers. The burden then disproportionately falls on the settlement 
sector. Garcea (2016) documents the municipal contributions to the Syrian refugee settlement process. However, these contributions were limited to advocacy (hosting welcome fair, supporting refugees in the media), indirect service provision (making city's existing services available) or at times taking on the role of a coordinator (that is, facilitating the efforts of various governments, organizations, or groups within the city). He also records some in-kind support, but only a handful of cities offered financial contributions. For instance, in 2016, the City of Edmonton provided all Syrian refugees with free transit passes to help remove mobility barriers to attend language classes and go to a doctor. The Province of Alberta made a few resettlement grants available to the settlement agencies and opened their health care systems for health screenings under the Interim Federal Health Program in the first year. Clearly, for future refugee resettlements, IRCC should seek active municipal as well as provincial role through bilateral federal-provincial/territorial cooperation agreements rather than keeping them at bay as silent bystanders.

Of course, the above findings are based on the study of only two cities in one province. Future research could include multiple small communities in different provinces to help generalize and validate the connection between the size of the city and the level of preparedness in welcoming newcomers. They should also strive to broaden the number of interviewees, especially PSRs and BVORs, to better understand if the settlement experience in small communities is mediated by the type of sponsorship. There is merit in scholars returning to the refugees we interviewed and asking similar questions to those we asked 2 years ago. This would help to ascertain if their issues and challenges have shifted since their initial year of settlement, and, above all, whether they are still living in Lethbridge.

\section{References}

Abu-Laban, B., Derwing, T., Krahn, H., Mulder, M., \& Wilkinson, L. (1999). The settlement experience of refugees in Alberta: a study prepared for citizenship and immigration Canada. Edmonton: Prairie Centre of Excellence for Research on Immigration and Integration and Population Research Laboratory.

Agrawal, S. K. (2018). Canadian refugee sponsorship programs: experience of Syrian refugees in Alberta, Canada. Journal of International Migration and Integration, 1-22. https://doi.org/10.1007/s12134-0180640-7.

Ashton, W., Pettigrew, R. N., \& Galatsanou, E. (2016). Assessment of settlement services systems in western and northern Canada: perceptions of settlement provider organizations. Canadian Ethnic Studies, 48(3), 69-89.

Bingley, J. (2016). The Story Bridge [Feature documentary filmed by members of Lethbridge's largest resettled refugee population]. Retrieved march 9, 2019, from https://www.ulethbridge. $\mathrm{ca} /$ prenticeinstitute/news/story-bridge-feature-documentary-filmed-members-lethbridge\%E2\%80\%99slargest-resettled-refugeepopulati. Accessed 9 Mar 2019.

Bonifacio, G. T. (2017). (Mis)Givings in a prairie city? Identity and belonging of Filipina (im)migrants in Lethbridge, Alberta. In G. T. Bonifacio \& J. L. Drolet (Eds.), Canadian perspectives on immigration in small cities (pp. 77-98). Cham: Springer International Publishing.

Bonifacio, G. T., \& Drolet, J. L. (2017). Introduction. In G. T. Bonifacio \& J. L. Drolet (Eds.), Canadian perspectives on immigration in small cities (pp. 1-17). Cham: Springer International Publishing.

Citizenship and Immigration Canada. (2001). Towards a more balanced geographic distribution of immigrants. Ottawa, ON: Author.

Clement, G., Carter, T., \& Vineberg, R. (2013). Case study: The realigned system of settlement service delivery in MB 1999 to 2013. Retrieved from https://umanitoba.ca/faculties/arts/media/CaseStudy_ RealignedSystemMB2.pdf 
Danso, R. (2002). From "there" to "here": an investigation of the initial settlement experiences of Ethiopian and Somali refugees in Toronto. GeoJournal, 56(1), 3-14.

Derwing, T. M., \& Krahn, H. (2008). Attracting and retaining immigrants outside the metropolis: is the pie too small for everyone to have a piece? The case of Edmonton, Alberta. Journal of International Migration and Integration / Revue de l'integration et de La Migration Internationale, 9(2), 185-202.

Derwing, T. M., \& Mulder, M. (2003). The Kosovar sponsoring experience in Northern Alberta. Journal of International Migration and Integration / Revue de l'integration et de La Migration Internationale, 4(2), $217-236$.

Drolet, J., \& Robertson, J. (2011). "In the smaller city, a settlement worker wears many hats": understanding settlement experiences in Kamloops, British Columbia. In D. Hiebert (Ed.), Our Diverse Cities: British Columbia (pp. 139-144). Ottawa: Citizenship and Immigration Canada. http://publications.gc. ca/collections/collection_2011/cic/Ci2-1-8-2011-eng.pdf. Accessed 7 Mar 2019.

Drolet, J., Robertson, J., Multani, P., Robinson, W., \& Wroz, M. (2008). Settlement experiences in a small city: Kamloops, British Columbia. Small Cities Imprint, 1(1), 21-30.

Economic Development Lethbridge. (2016). Major Employers. Lethbridge. Retrieved from https://chooselethbridge.ca/index.php?seotitle=major-employers. Accessed 1 Mar 2019.

Economic Development Lethbridge. (2017). Lethbridge Commercial and Industrial Development Study. Retrieved from http://www.lethbridgechamber.com/lethbridge-commercial-industrial-development

El-Bialy, R., \& Mulay, S. (2015). Two sides of the same coin: factors that support and challenge the wellbeing of refugees resettled in a small urban center. Health \& Place, 35, 52-59.

Ellis, G. (2001). A short history of Lethbridge, Alberta. Retrieved March 1, 2019 from https://web.archive. org/web/20050923135454/http:/www.lethbridge.ca/home/Enjoying\%2BLethbridge/Picture\%2 BGallery/Short\%2BHistory.htm. Accessed 1 Mar 2019.

Enns, R., \& Carter, T. (2009). Refugee housing trajectories in Edmonton, Calgary and Winnipeg. In T. Carter, T. M. Derwing, L. Ogilvie, \& T. Wotherspoon (Eds.), Our Diverse Cities: The Prairies (pp. 109-114). Ottawa: Citizenship and Immigration Canada. http://publications.gc.ca/collections/collection_2010 /cic/Ci2-1-6-2009-eng.pdf. Accessed 7 Mar 2019.

Esses, V. M., Hamilton, L. K., Bennett-AbuAyyash, C., \& Burstein, M. (2010). Characteristics of a welcoming community. Retrieved from http://p2pcanada.ca/library/characteristics-of-a-welcomingcommunity-report/

Esses, V. M., Medianu, S., \& Lawson, A. S. (2013). Uncertainty, threat, and the role of the media in promoting the dehumanization of immigrants and refugees. Journal of Social Issues, 69(3), 518-536

Fang, T., Sapeha, H., \& Neil, K. (2018). Integration and retention of refugees in smaller communities. International Migration, 56, 83-99. https://doi.org/10.1111/imig.12517.

Frideres, J. S. (2006). Cities and immigrant integration: the future of second- and third-tier centres. In J. S. Frideres (Ed.), Our Diverse Cities (pp. 3-9). Ottawa: Citizenship and Immigration. http://publications.gc. ca/collections/collection_2007/cic/Ci2-1-2-2006E.pdf. Accessed 7 Mar 2019.

Garcea, J. (2016). The resettlement of Syrian refugees: the positions and roles of the Federation of Canadian Municipalities and its members. Canadian Ethnic Studies, 48(3), 149-173.

George, U., \& Tsang, A. K. T. (2000). Newcomers to Canada from the former Yugoslavia. International Social Work, 43(3), 381-393.

Hallström, L. K. (2018). Similarity, difference, and change in rural communities: How internal dynamics shape innovation. Paper presented at the Enhancing Inclusivity in Rural Canada Conference, Camrose, Alberta, Canada.

Hansson, E. K., Tuck, A., Lurie, S., \& McKenzie, K. (2012). Rates of mental illness and suicidality in immigrant, refugee, ethnocultural, and racialized groups in Canada: a review of the literature. The Canadian Journal of Psychiatry, 57(2), 111-121.

Hiebert, D. (2000). Immigration and the changing Canadian city. The Canadian Geographer/Le Géographe Canadien, 44(1), 25-43.

Hiebert, D. (2017). Immigrants and refugees in the housing markets of Montreal, Toronto and Vancouver, 2011. Canadian Journal of Urban Research, 26(2), 52-78.

Hou, F., \& Beiser, M. (2006). Learning the language of a new country: a ten-year study of English acquisition by south-east Asian refugees in Canada. International Migration, 44(1), 135-165.

Hyndman, J., Schuurman, N., \& Fiedler, R. (2006). Size matters: attracting new immigrants to Canadian cities. Journal of International Migration and Integration / Revue de l'integration et de La Migration Internationale, 7(1), 1-25.

IRCC (Immigration, Refugees and Citizenship Canada). (2018). Syrian refugees - monthly IRCC updates. https://open.canada.ca/data/en/dataset/01c85d28-2a81-4295-9c06-4af792a7c209. Accessed 9 Mar 2019. 
Johnston, A., \& den Otter, A. A. (1985). Lethbridge: a centennial history. Lethbridge: City of Lethbridge and The Whoop-up Country Chapter, Historical Society of Alberta.

Klingbeil, A. (2016). How Lethbridge became Canada's Bhutanese capital. Calgary Herald. Retrieved from https://calgaryherald.com/news/local-news/how-lethbridge-became-canadas-bhutanese-capital. Accessed 7 Mar 2019.

Kovacs, M. L. K. (1981). From industries to farming. Hungarian Studies Review, VIII(1), 45-60.

Krahn, H., Derwing, T. M., \& Abu-Laban, B. (2005). The retention of newcomers in second- and third-tier Canadian cities. International Migration Review, 39(4), 872-894.

Li, P. S. (2008). Chinese immigrants on the Canadian prairie, 1910-47. Canadian Review of Sociology/Revue Canadienne de Sociologie, 19(4), 527-540.

Lo, L., \& Teixeira, C. (2015a). Immigrants doing business in a mid-sized Canadian city: challenges, opportunities, and local strategies in Kelowna, British Columbia. Growth and Change, 46(4), 631-653.

Lo, L., \& Teixeira, C. (2015b). Sustaining immigrant entrepreneurship in small- and medium-sized cities. Journal of Entrepreneurship and Innovation in Emerging Economies, 1(2), 146-162.

Radford, P. (2007). A call for greater research on immigration outside of Canada's three largest cities. In B. Reimer (Ed.), Our Diverse Cities (pp. 47-51). Ottawa: Citizenship and Immigration Canada. http://publications.gc.ca/collections/collection_2008/cic/Ci2-1-3-2007E.pdf. Accessed 7 Mar 2019.

Rural Development Insitute (2016). Immigration in 5 rural Manitoba communities with a focus on refugees: Boissevain-Killarney case. https:/www.brandonu.ca/rdi/files/2016/09/Immigration-in-5-Rural-ManitobaCommunities-with-a-Focus-on-Refugees-Case-Studies-August-2016.pdf. Accessed 9 Mar 2019.

Ruttan, G. (2018). Coal mining's boom and bust. Retrieved from https://www.galtmuseum.com/articles/2018 /10/15/coal-minings-boom-and-bust. Accessed 7 Mar 2019.

Sethi, B. (2013). Newcomers health in Brantford and the counties of Brant, Haldimand and Norfolk: perspectives of newcomers and service providers. Journal of Immigrant and Minority Health, 15(5), 925-931.

Sherrell, K., Hyndman, J., \& Preniqi, F. (2004). Sharing the wealth, spreading the 'burden'? The settlement of Kosovar refugees in smaller B.C. cities. Working paper no. 04-06. Vancouver: RIIM.

Simich, L., Beiser, M., Stewart, M., \& Mwakarimba, E. (2005). Providing social support for immigrants and refugees in Canada: challenges and directions. Journal of Immigrant and Minority Health, 7(4), 259-268.

Stephenson, A. (2019). Federal government creates immigration pilot program in agriculture. Calgary herald. March 20th. https://calgaryherald.com/business/local-business/federal-government-createsimmigration-pilot-program-for-agriculture. Accessed 7 Mar 2019.

Tams, K. (2014). Lethbridge home to the largest Bhutanese community in Canada. Retrieved from https:/globalnews.ca/news/1329208/lethbridge-home-to-the-largest-bhutanese-community-in-canada/. Accessed 9 Mar 2019.

Teixeira, C. (2009). New immigrant settlement in a mid-sized city: a case study of housing barriers and coping strategies in Kelowna, British Columbia. The Canadian Geographer/Le Géographe Canadien, 53(3), 323-339.

Teixeira, C., \& Drolet, J. L. (2018). Settlement and housing experiences of recent immigrants in small- and mid-sized cities in the interior of British Columbia (Canada). Journal of Housing and the Built Environment, 33(1), 19-43.

Teixeira, C., \& Li, W. (2009). Immigrant and refugee experiences in North American cities. Journal of Immigrant \& Refugee Studies, 7(3), 221-227.

UNHCR (n.d.). Syria emergency http://www.unhcr.org/syria-emergency.html. Accessed 30th December 2019.

Walton-Roberts, M. (2005). Regional immigration and dispersal: lessons from small- and medium-sized urban centres in British Columbia. Canadian Ethnic Studies Journal, 37(3), 1-22.

Walton-Roberts, M. (2006). Regional immigration and dispersal: lessons from small- and medium-sized urban centres in British Columbia. In J. S. Frideres (Ed.), Our Diverse Cities: 11th International Metropolis Conference (pp. 158-162). Ottawa: Citizenship and Immigration Canada. http://publications.gc. ca/collections/collection_2007/cic/Ci2-1-2-2006E.pdf. Accessed 7 Mar 2019.

Williams, A. M., Kitchen, P., Randall, J., Muhajarine, N., Newbold, B., Gallina, M., \& Wilson, K. (2015). Immigrants' perceptions of quality of life in three second- or third-tier Canadian cities. The Canadian Geographer / Le Géographe Canadien, 59(4), 489-503.

Wood, P. B., McGrath, S., \& Young, J. (2011). The emotional city: refugee settlement and neoliberal urbanism in Calgary. Journal of International Migration and Integration / Revue de l'integration et de La Migration Internationale, 13(1), 21-37.

Yamagishi, N. R. (2010). Japanese Canadian journeys: the Nakagama story. Bloomington, IN: Trafford Publishing.

Publisher's Note Springer Nature remains neutral with regard to jurisdictional claims in published maps and institutional affiliations. 